\title{
Holland as other place and other time: alterity in projected tourist images of the Netherlands
}

\author{
Bouke van Gorp · Tine Béneker
}

Received: 20 March 2006/Accepted: 2 May 2007/Published online: 30 May 2007

(C) Springer Science+Business Media B.V. 2007

\begin{abstract}
Geographers show keen interest in projected images employed in tourism as these images both reflect the ideas of the image producers and influence tourists' perceptions and (spatial) behaviour. This article focuses on intentional and unintentional projected images of the Netherlands. The former is especially selective: it relies on stereotypes and presents Holland. The unintentional projected image created in four travel guides is less stereotyped. While the focus is still on Holland, other areas of the country are presented as well. Both intentional and unintentional projected images rely on 'othering' and 'alterity' to make the Netherlands a unique destination and to offer the tourists a trip that is far from everyday life. However travel guides use 'alterity' in different ways and at different levels of scale to create a regional geography of the Netherlands as well.
\end{abstract}

Keywords Intentional and unintentional projected images - Representation - Travel guides · The Netherlands · Holland

B. van Gorp $(\varangle)$ · T. Béneker

Human Geography and Planning, Faculty of Geosciences Utrecht University, Heidelberglaan 2, P. O. Box 80115, 3508 TC Utrecht, The Netherlands

e-mail: b.vangorp@geo.uu.nl

\section{Introduction}

With the rise of mass tourism and expanded communication technologies there has been an enormous increase in the production of tourist information in advertisement, brochures, Web pages, travel guides and travel programmes on television (Werthner and Klein 1999). These sources play an important role in tourism according to McGregor (2000, p. 29) as "the product, the experience and destination, is normally purchased prior to arrival'.

Information sources influence the practices and spatial behaviour of millions of tourists (Markwick 2001; Gilbert 1999). Most of the sights tourists visit or gaze upon are already known to them. Brochures, travel guides and holiday pictures from friends and family show exactly these very sights. Photographing these sights and showing these pictures at home closes the 'circle of representation' (Jenkins 2003). The information sources thus give an insight into the consumption of the place and landscape by tourists. The information from these sources moreover reflects the views of its producers on the destination as a tourism product. It shows what they think is interesting for tourists to see or experience.

There are different sources of tourist information and each source communicates a distinctive type of tourist images. A tourist image is a simplified, schematic and constructed reproduction of the destination (Bockhorn 1997). Kozma and Ashworth (1993, p. 129) make the distinction between 
intentional projected images, the promotional image created by official tourist organisations, and unintentional projected images that appear in tourist guides, films or news broadcast. ${ }^{1}$ Tourist advertisements and brochures used for place promotion deliberately aim at selling a place by using the unique selling points of places (Kotler et al. 1993). This leads to simple, appealing images with the use of slogans and stereotypes. Travel guides also mediate the relationship between tourists and destination (Bhattacharyya 1997), but their information selection might be less based on marketing techniques (Van der Vaart 1998).

Presently, the communication of tourist images is a research theme in tourism studies and in (cultural) geography (for example in several case studies by Goss 1993; Bell 1995; Béneker 2003; Hopkins 1998; Gilbert 1999; Jenkins 2003; Nelson 2005). Place promotion is a well-documented field of study, but the majority of the attention is paid to the public policy and marketing side of it, and not to the image communication part of place promotion (Hopkins 1998). In the context of tourism marketing, Dietvorst and Ashworth (1995) use the idea of the symbolic transformation of tourist areas. The tourist board (the supply side) transforms the area symbolically in their marketing campaigns, and tourists (the demand side) transform their mental image of the place during their visit. The renewed interest in processes of representations of place results in deconstructions of tourist images that give insight in current meanings attached to places (Hopkins 1998). Some geographers even argue that travel guides can be seen as popular geographical knowledge influencing popular perceptions of places (for example Gilbert 1999; Van der Vaart 1998; Argreiter 2000).

This article presents a critical interpretation and comparison of the communication of intentional and unintentional projected images of the Netherlands. Before turning to this analysis we will look into the specific process of communicating place images in tourist information sources.

\footnotetext{
1 These projected images are always created intentionally. Intentional and unintentional here refers to the influence of the organisation for official tourist promotion on these projected images. Images projected in travel guides or travel programmes on television are created autonomously.
}

\section{Tourist images}

One of the most important concepts used in studies of tourist image communication is the tourist gaze (Urry 1990). The tourist gaze is the way tourists look at different destinations. This gaze is not only a collection of artifacts or objects, it also refers to the 'view' behind it. This can be, for example, a more romantic view or a more spectacular or artistic view.

According to Urry (1995, p. 132) the motivation for tourists to travel is to look 'upon aspects of landscape or townscape which are distinctive, which signify an experience which contrasts with everyday experience'. As such, tourist destinations tend to be represented as the opposite of the place where tourists come from, generally urbanised Western societies. This process of 'othering' is also inherent in 'alterity' (Hopkins 1998).

The most obvious evidence in the use of 'the other' is the promotion of non-Western countries among Western tourists. Echtner and Prasad (2003) analysed the images of 12 Third World Countries in tourist brochures and they observed three myths that were communicated: the myth of the unchanged (a timeless place, mostly used for Oriental destinations), the myth of the unrestrained (the contemporary paradise, mostly used for luxurious sand and sea destinations), and the myth of the uncivilised (frontier destinations where civilisation is absent and nature is savage). Goss (1993) described the process in the marketing of the state of Hawaii to USA citizens. Hawaii is promoted as a 'counter-image' of the tourists' urban daily lives, as a signifier of alterity together with its tropes of paradise, marginality, feminity, and aloha. Even over time, when target groups and projected experiences of Hawaiian vacations change, the element of alterity has been kept alive. Not only marketing information sources spread these images of the other. In the Lonely Planet travel guide India is characterised as the combination of 'past glory' and 'exotic present' (Bhattacharyya 1997).

Within the Western world the use of othering is common as well: Australia is sold as 'paradise' and 'adventure' in the campaigns targeting European tourists (Waitt 1997). Within Europe the image of the Mediterranean is based on othering as is shown for example by Markwick's (2001) analysis of postcards from Malta. Originally the image was very exoticed 
as a sun and sea destination. It is now diversified with an authenticity notion, by which the country's rich cultural heritage is promoted.

For rural areas in Western countries, the study by Hopkins (1998) is very useful. He identifies the myths used to promote a rural region in Ontario, Canada. The most important myths are the natural environment, the past and the community followed by the myths of 'spatial exotica' and the 'pastoral retreat'. The dominant representations of the rural in these advertisements according to Hopkins (1998, p.78) express: "alterity: the rural is presented as some place other than the urban, as some time other than the present, as some experience other than the norm'. Comparable findings can be extracted from studies of the predominantly rural Irish tourist image. This image is the opposite of England, modern society and urban industrialised Europe (Kneafsey 1998, p. 112). The Irish Tourist Board used romantic visions of the landscape in campaigns to lure German tourists, by referring to painting traditions (Bell 1995). Parts of Ireland are also overrepresented as the western landscape functions as a shorthand for the landscape in general (Nash 1993 in Kneafsey 1998). This indicates a spatially selective geography in the projected images.

The representation of urban areas of the Western world has also been analysed. Van der Vaart (1998) for example studied 12 travel guides of Paris, published between 1952 and 1997 for a Dutch public, and Argreiter (2000) analysed six Italian guidebooks for Munich. The analyses of both researchers, first, show that contemporary travel guides have a strong focus on artifacts such as monuments, churches and museums. Second, the information is also spatially selective. Munich is reduced to the historic city centre, the 'Altstadt'. Van Gorp (2003) found a similar spatial selectivity towards (parts of the) historic city centre in both travel guides and city tours of Dutch cities. Van der Vaart (1998) moreover observed that for Paris this spatial selection hardly changed in 45 years.

All three geographers just mentioned conclude that travel guides in general lack geographical contexts. Usually the historical, architectural and artistic contexts predominate (Van der Vaart 1998). As a result Munich is idealised (or perhaps simplified) in all travel guides. The resulting image refers to Munich as a city of art and to the past when Munich was a royal seat. Alongside this (art) historic image, Munich is characterised by Oktoberfest stereotypes: beer, traditional dress and oompahpah music. There is no mention of contemporary problems or debates in the city, even when it could be useful to create a better understanding of the city.

Projected images are constructions and selections. Often these images create their own geography. Tourists are directed to a specific part of the destination and certain areas or landscapes can come to represent the whole country. Intentional projected images moreover rely on stereotypes, as there is limited space for information in most promotional materials. A central element in both intentional and unintentional projected images is 'difference'. Official tourist promoters try to stress the 'unique selling points' of destination. Authors of travel guides try to create an experience that is different from the daily life of the tourists. For Western countries this difference is found in 'other times' and 'other experiences'.

\section{Methods}

This article focuses on the image communication of the Netherlands to tourists and takes both the intentional projected image as created by the National Tourist Board (NBTC) and the unintentional projected image communicated by travel guides into consideration. Which images of the Netherlands are communicated to tourists by these information sources? How would geographers interpret these images? The analysis starts with the identification of the stereotypes used in the projected images. Then it will turn to spatial selectivity and finally to the use of alterity.

The intentional projected image of the Netherlands is well known and reasonably well documented. The description of intentional projected images is therefore mostly based on the literature. The Web pages of the national tourist board will be used as an illustration. By comparison, the unintentional projected image is not as well documented. Therefore a content analysis of four travel guides of the Netherlands has been performed. The four travel guides are: the German-language ADAC Reiseführer Niederlande (2004), the English-language Lonely Planet The Netherlands (2004), the Dutch Capitool reisgids Nederland (2002) and the Dutch edition of Michelin's Guide Vert for The Netherlands (2001). The main 
characteristics of these travel guides are summarised in table 1. The ADAC Reisefuihrer is a richly illustrated travel guide with a large section containing (regionally organised) place descriptions. This travel guide pays attention to a variety of cultural attractions, cities and beaches. The Lonely Planet is a travel guide with a lot of practical information concerning where to stay or eat. The Lonely Planet is usually considered to be the travel guide for backpackers. The Dutch edition of Michelin's Guide Vert (Groene Gids) discusses places not by region but in alphabetic order. It is written for a general public that is interested in history and culture. The Capitool reisgids is the most voluminous of the four travel guides. The Capitoolseries are Dutch editions of the Dorling and Kindersley Eyewitness series, which are presented in the Netherlands as "the guide that shows what others only write about', a claim substantiated by the huge number of pictures in this travel guide.

The content analysis interprets the unintentional projected image by focusing on three aspects: stereotypes, geography (spatial selectivity) and alterity. The occurrence of stereotypes in the representations was analysed by counting the number of times the stereotypical elements found in the intentional projected image also occurred in pictures in the travel guides. The spatial selectivity (where tourists should go) of the unintentional projected image was measured by the number of pictures and amount of text per province in the travel guides. ${ }^{2}$ Spatial selectivity focused especially on the distinction between Holland and the other provinces. It was expected that Holland receives much more attention and is sometimes even equated with the whole of the Netherlands. Although Holland is internationally often used as the name for the whole country, Holland and The Netherlands are not the same. Holland is just a part of the Netherlands (the western provinces: Noord- and Zuid-Holland (see Fig. 1)). Since the 16th century Holland has been the economic and political core of the Netherlands. Inhabitants of other provinces such as Friesland in the north or Limburg in the south will stress the cultural

\footnotetext{
${ }^{2}$ In general it was possible to determine the province in which a picture was taken by looking at the picture and reading the caption. However, this was not possible for every picture. Therefore pictures of famous (historical) Dutch personalities were excluded, as were pictures of pieces of art (such as paintings) and museum collections. For the texts only the pages of the place descriptions were counted.
}

differences of their areas compared to Holland. Geographically speaking there are visible differences as well in the landscape. Barends et al. (1995) show the variety of landscapes present in the Netherlands. Whereas Holland is well known for its fenlands, large parts of the south and east of the country are characterised by higher sandy soils. Therefore, using Holland as a synonym for the Netherlands is similar to using England for the UK or Russia for the whole former territories of the USSR. Finally, what landscape to gaze upon and the use of alterity were analysed from the pictures. First, it was established what kind of area or landscape a picture showed or referred to. Then it was determined whether the picture represented 'other times' (evidenced by historical buildings, historical streetscapes or nostalgic images) or 'other experiences' (leisure activities, agriculture or nature).

\section{The intentional projected image: Holland, land of tulips, windmills and clogs}

The intentional image of the Netherlands projected on foreign tourists is well known. At the core of the intentional projected image of the Netherlands is a country of clogs, windmills, tulips, and cheese. Furthermore, the Netherlands is presented as an open, flat, green country with lots of water and an occasional windmill: a 'typical' polder in short. It is a highly nostalgic picture of the Netherlands, reinforced by the inclusion of images of women in traditional dress. This repertoire is used a lot by the Dutch tourism industry. Tourist offices all over the country sell clogs, mugs with cows, tulip-shaped umbrellas, Delft ware and postcards with pictures of windmills, tulips and cheese.

However the intentional projected image of the Netherlands is not solely rural. There is a second component: the 'old Holland' (Oud Hollandse) cities. This is a historic townscape, with mostly 17 th-18thcentury houses and canals, but also with (Medieval) churches, city walls or towers and a city hall. ${ }^{3}$ This

\footnotetext{
${ }^{3}$ Dahles (1998, p. 55) refers to these townscapes as "Vermeer townscapes',.
} 


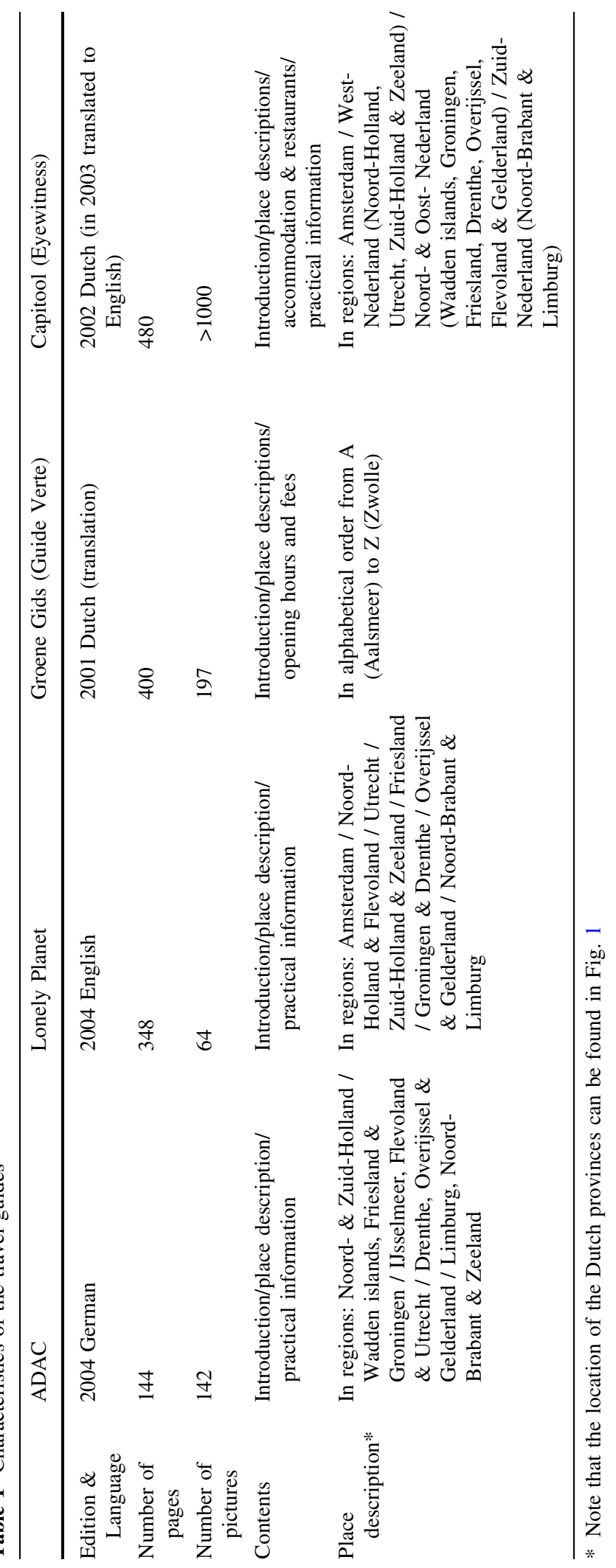




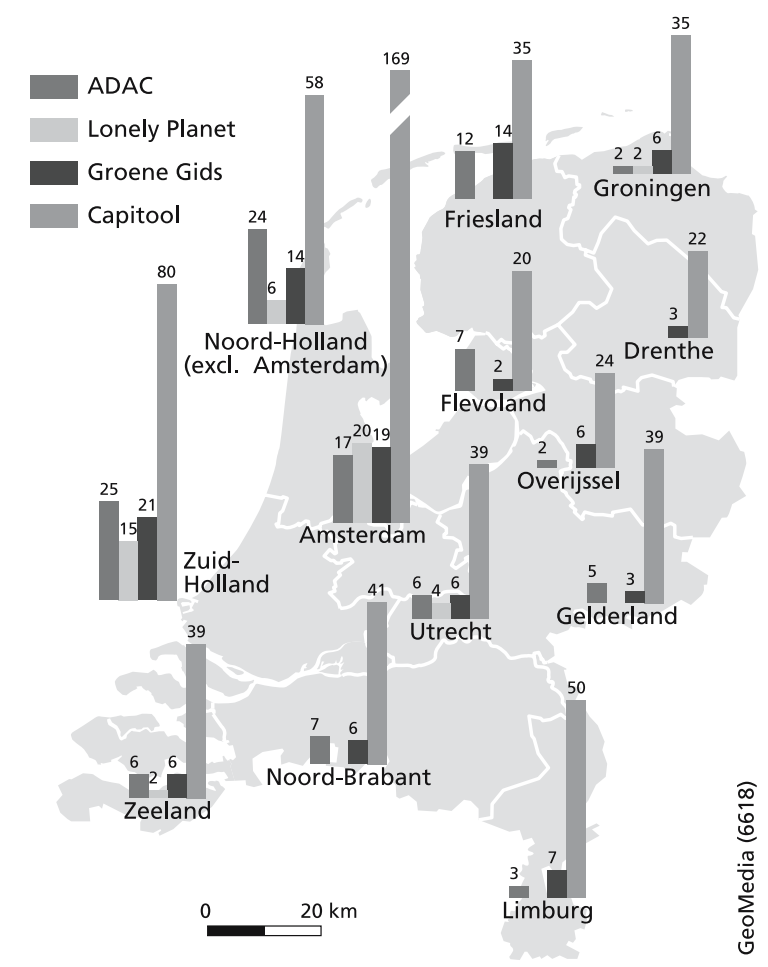

Fig. 1 Pictures of each province. The number of pictures in the travel guides that can be attributed to respective provinces. It is clear that Noord- and Zuid-Holland and Amsterdam dominate the travel guides in this respect. Note that Amsterdam

image reflects the 'glory' of the cities in Holland and the Dutch Golden Age in general. This representation is also nostalgic: the pictures show the best-preserved parts of Dutch cities, usually without 'obtrusive' elements such as modern buildings, people and cars. This second component of Dutch tourism assures that the Netherlands has its share in the overall popularity of cultural tourism and city trips.

The Web pages www.Holland.com are created by NBTC and are therefore part of the intentional project image. The top row of pictures (header) is the first thing visitors of these Web pages see. On the French, Italian and Spanish homepages ${ }^{4}$ of the

\footnotetext{
$\overline{4}$ These Web pages allow visitors to choose their country of origin. By doing so, visitors are redirected to Web pages in their own language and seemingly based on their tourism preferences. This analysis was conducted in 2005. In January 2006 the layout of parts of the Web pages (the Dutch and German pages) was revamped drastically. The new layout shows only one large picture of orange tulips. Later on in 2006 the Web pages for other countries of origin were given this new lay out as well.
}

is part of the province of Noord-Holland. As Amsterdam gets a lot of attention in travel guides, it is presented separately here and in figure 2

NBTC, one sees two windmills, some tulip fields, two typical Amsterdam canal houses, a sailboat, a family on bicycles and a castle. The German homepage shows pictures of: a cow, Van Gogh's self-portrait, clogs and a bike, tulips, 17th-century gables, a crate of strawberries of Holland Veilingen (fruit and vegetable auctions), a bike and a lighthouse. The NBTC homepages for US and Canada show windmills, canal houses in Amsterdam, a painting by Van Gogh, a modern bridge in Amsterdam and clogs.

This intentional projected image of the Netherlands is spatially selective: what is presented is Holland, not the Netherlands. The NBTC even uses the Internet address www.Holland.com. They contend that the name 'Holland' is better known abroad than the official name the Netherlands. The landscapes and townscapes on display are typically Holland. Jansen (1994) found that in NBTC brochures for the German and British market pictures of fenlands (laagveenweidegebied) and (old) polders 
were overrepresented. ${ }^{5}$ Moreover, the Netherlands was represented as a waterrich country. Stretches of water were shown in the majority of pictures, even in instances where drier sandy landscapes or cities were depicted.

Not only the landscape on display is typically Holland. The tourist gaze spatially focuses on Holland as well. The NBTC Web pages always have a (not to miss) section on Amsterdam. Many of the other cities that receive attention on the Web pages (for example the Autres Villes on the French pages or the Stroll along cities on the UK and Ireland pages) are situated in Holland as well. There is limited attention for other regions outside Holland.

\section{Origins of the intentional projected image}

It is interesting to see how elements, which are in themselves not typically Dutch, together came to represent the country. Tulips were imported to the Netherlands from Turkey in the 16th century, windmills can be found in other countries (for example, Spain) and cheese is produced and eaten-although in many varieties-all over the world. These stereotypes nevertheless act as strong symbols for tourism in the Netherlands. Perhaps they have to make up for the lack of a true landmark. The Netherlands has no single building or structure that stands out and that is immediately associated with the country (Dahles 1998; Munsters 2001). There is no building or structure that is a must-see tourist attraction in the Netherlands like the Eiffel tower is for Paris and France as a whole. Taking a picture of a random windmill seems to suffice for most tourists.

As stated before, projected images often rely upon othering and alterity. There is some uniqueness in the 'struggle against water' theme and the flatness of the country. This explains the number of pictures of polders and stretches of water in general. Nostalgia plays a role in 'othering' as well: it presents an 'other time'. This nostalgic image dates back to the 19th century when well-to-do citizens and the

\footnotetext{
${ }^{5}$ Barends et al. (1995) divide the country into 11 different types of landscapes. The kind of landscape found in the projected image is mainly found in the low-lying western areas. The east and south of the country for example mainly consist of higher sandy soils.
}

intelligentsia became more and more interested in (an idealised version of) folk life and culture such as traditional dress and interiors (De Jong 2001). ${ }^{6}$ Painters of the Haagse School ${ }^{7}$ shared this interest in the traditional (and quickly disappearing) ways of life of farmers and fishermen. They painted fishermen with their boats on the beach of Scheveningen and farmers in 't Gooi. ${ }^{8}$ As their paintings were sold worldwide, these became powerful representations of the Netherlands.

Not only painters from the Haagse School were involved in this nostalgic interpretation of the Netherlands. American art historian Stott (1998) relates how by the end of the 19th century a particular group of Americans showed interest in the 'traditional' Netherlands. These descendants of European immigrants objected to the predominantly English interpretation of American history and identity. They looked for their continental European roots and thus got interested in the founders of Nieuw Amsterdam. This created a 'Holland revival' or 'Holland mania'. The rural idyll ${ }^{9}$ created by the painters of the Haagse School was reinforced by American painters visiting the Netherlands and painting similarly nostalgic pictures. Furthermore, American visitors took souvenirs, such as regional traditional dress, home with them. This all led to a large-scale spreading and reproduction of an idealised, nostalgic image of the Netherlands. De Jong (2001, p. 186) states that with this interest in the Netherlands the image of clogs, windmills and the struggle against water was born.

\footnotetext{
${ }^{6}$ This interest is reflected in the exhibitions of traditional dress by different countries at world exhibitions and by the rise of the open-air museums (e.g. Skansen in Sweden) (De Jong 2001).

${ }^{7}$ Haagse School: group of painters that lived in Den Haag at the end of the 19th century. Famous painters from this group are: Hendrik Willem Mesdag, Jozef Israels, the brothers Maris and Anton Mauve (Kunstbus 2005). Mesdag is famous in the Netherlands for amongst others his Panorama of Scheveningen. Mauve is well known for his paintings of flocks of sheep grazing on the heathlands of ' $t$ Gooi.

8 't Gooi is an area close to both Amsterdam and Utrecht; it is the most eastern part of the province of Noord-Holland. The area is characterized by sandy landscapes.

${ }^{9}$ A nostalgic perception or projection of rural areas as timeless and unchanged. A romanticised and conservative view of a peaceful countryside where life is simple, communities are still close-knit and nature at hand (Daniels et al. 2005, Van Dam et al. 2002).
} 
Windmills and traditional dress was all that tourists wanted to gaze upon.

This nostalgic image was reinforced by the introduction and popularity of the postcard (De Jong 2001). In the beginning of the 20th century the postcard quickly developed as both a means of communication and a souvenir (Dietvorst 2002). Postcards of the Netherlands seem to follow the example set by the Haagse School and thus depicted people in traditional dress. However, the postcards were reproduced on a far larger scale than those paintings and therefore reached more people.

The Holland mania meant not only the creation of a nostalgic rural image of the Netherlands. The revival of Holland in America also created an interest in the Golden Age of Holland and the 17th-century townscapes belonging to that age. This interest in the Dutch renaissance townscapes coincided with a similar reminiscence in the Netherlands. Nineteenth-century nation building in the Netherlands implied the creation of a national history. The golden age of Holland was presented as the Golden Age in history books. The prevalent architecture of this Golden Age (Hollandse Renaissance) was re-used for public buildings such as courts, railway stations, government offices and the Rijksmuseum (Van Gorp and Renes 2003). Oud-Hollandse cities or townscapes could be found in fairs and world exhibitions as well (De Jong 2001). The popularity of 17thcentury townscapes was also stimulated by the romantic painter Springer who painted many Oud Hollandse townscapes (De Jong 2001).
A last explanation for the overrepresentation of Holland in the intentional projected image is the position of Amsterdam. Dahles (1998, p. 62) states that Amsterdam is the selling point for the Netherlands. For many foreign tourists Amsterdam is the focal point of their visit to The Netherlands. After sightseeing the city and visiting some of its museums, tourists will take trips to the Holland countryside from Amsterdam. NBTC (2005) provides the following tip to tourists

In addition to tours through the city, various excursions take you to towns and places around Holland's capital. You can go to Marken, Edam, Alkmaar and the windmills of Zaanse Schans, the Keukenhof and Waterland. Choose from scores of excursions by bike, on foot, by boat \& coach.

\section{Unintentional projected image—four travel}

\section{guides}

The front covers of three of the travel guides resonate with the stereotypes of the intentional projected image. The Lonely Planet's front cover shows yellow tulips. The front cover of the $A D A C$ travel guide depicts a rural image: the picture shows a windwill in a polder landscape. On the cover of Michelin's Groene Gids there are three pictures: one of tulips, one of cheeses and one of the windmills of Kinderdijk. In the travel guides, however, the stereotypes are

Table 2 Pictures of stereotypes in travel guides

\begin{tabular}{lcccr}
\hline Stereotypes & ADAC & Lonely Planet & Groene Gids & Capitool \\
\hline Windmills & 2 & 4 & 5 & 15 \\
Clogs & 1 & 1 & 0 & 1 \\
Tulips & 3 & 5 & 6 & 10 \\
Cheese & 3 & 2 & 2 & 11 \\
Traditional dress & 2 & 2 & 49 & 183 \\
Water & 59 & 13 & 3 & 8 \\
Waterworks modern & 3 & 0 & 2 & 8 \\
Waterworks traditional & 1 & 0 & 4
\end{tabular}

Number of pictures in each travel guide depicting the stereotypes from the intentional projected image of the Netherlands: windmills, clogs, tulips, cheese, traditional dress and (the struggle against) water

The table presents absolute figures, because pictures can show more than one symbol at the time. The number of pictures in each travel guide: ADAC 142; Lonely Planet 64; Groene Gids 197 and Capitool a little over 1000 (but the pictures from the sections accommodation \& restaurants, and practical information-160 - were not included) 
by no means predominant. The number of pictures of cheese, windmills or tulips is limited (see Table 2). Water, however, is present in a reasonably large number of pictures of both urban and rural areas. The $A D A C$ shows water in $40 \%$ of the pictures, the Lonely Planet in 20\%, the Groene Gids in $25 \%$ and the Capitool in $22 \%$ of the pictures.

Just like the intentional projected image the tourist gaze the travel guides present is spatially selective. Travel guides pay much more attention to Holland (the provinces of Noord- and Zuid-Holland) than to the other provinces. This is demonstrated in Figs. 1 and 2, which show the amount of texts and number of pictures for each province. Note that in these figures Amsterdam is presented separately from the province of Noord-Holland in which it is located. This demonstrates the strong focus on Amsterdam of these unintentional projected images. There are some differences among the travel guides. The Groene Gids only devotes $46 \%$ of its text pages to Holland, the Lonely Planet up to $65 \%$. Of the pictures that could be attributed to a province between $47 \%$ (Capitool) and $84 \%$ (Lonely Planet) were taken in Holland. The Lonely Planet has the most Hollandcentred tourist gaze. The other provinces get a more or less equal share of the pages or pictures left in each travel guide: the average score is around 5\%, although Drenthe is clearly the worst off.

The travel guides present both urban and rural landscapes as places to gaze upon. However the focus seems to be more on urban landscapes (Table 3). Again the travel guides differ in the image they present. The Lonely Planet is concentrated on cities, while the Groene Gids is more 'rural' than the other travel guides. In the ADAC the gaze is also directed towards the beaches which traditionally host large numbers of German tourists.

An important characteristic of projected images was the use of alterity and othering. Two kinds of otherness can be identified: 'other times' and 'other experiences'. For both the urban and rural landscapes the gaze is directed at other times (see Table 4). In urban areas other times are presented by pictures of monumental buildings and historic townscapes. Other times in the countryside are presented by nostalgic images, by rural heritage (old farm buildings for example) and by other kinds of heritage, notably castles.

Very few pictures refer to working in modern industrial or commercial areas. If there is such a picture, it is likely to be one of the harbour of Rotterdam. If a person is depicted working, it is usually a craftsman performing a traditional craft or someone working for tourists. However, most of the people in the pictures are engaged in leisure activities: sightseeing, seated in front of a café having a drink or meal, or enjoying outdoor activities (biking, sailing). In rural areas other experiences not only relate to non-work activities but also to nonurban experiences: nature and agriculture. The Capitool and Groene Gids do to some extent show nature, especially when presenting areas other than Holland. All four travel guides contain some pictures relating to agriculture. However, what is shown is not truly modern contemporary agriculture. There seems to be a nostalgic bias in pictures of agriculture. A number of pictures show the modern agricultural practices of cultivating the stereotypical tulips. Other pictures for example combine modern equipment with historic farm buildings. ${ }^{10}$ The castles mentioned before not only present other times, they also present other experiences: the way of life of a elite class.

One aspect of the projected image of travel guides has not yet been mentioned. All four travel guides expect tourists to visit museums. Travel guides show pictures of museum buildings, interiors and of items from the museum collection. Van der Vaart (1998) found a similar focus on museums in the travel guides of Paris. This gaze is linked to the focus on historic and monumental buildings. Travel guides expect tourists to be interested in art history. Visiting a museum can, however, be seen as part of other experiences as well. Visiting a museum is linked to leisure and many tourists only visit museums during their holidays (Munsters 2001).

In short, travel guides present more than the stereotypes, but their focus is on Holland. What results is an image of a country full of historic towns and cities of nostalgic rural areas and of museums and castles. The Netherlands is not a country of ordinary Dutch people. The people in the pictures work as craftsmen, wear traditional dress or have a drink or meal outdoors. The gaze(s) of the four travel guides differ in some respects. These differences relate to the expected interest of the target group

\footnotetext{
${ }^{10}$ Interestingly the Capitool travel guide contains pictures of fisheries, which evoke little nostalgia given the setting. Other travel guides do not show fisheries.
} 
Table 3 What landscape to gaze upon?

\begin{tabular}{lcccc}
\hline & ADAC & Lonely Planet & Groene Gids & Capitool \\
\hline Urban landscapes & $60 \%$ & $80 \%$ & $50 \%$ & $58 \%$ \\
Rural landscapes & $23 \%$ & $14 \%$ & $32 \%$ & $34 \%$ \\
Beach & $10 \%$ & $2 \%$ & $2 \%$ & $2 \%$ \\
\hline
\end{tabular}

Percentage of pictures presenting urban, rural or beach landscape. The numbers do not make up $100 \%$ as not all pictures can be placed in one of these three categories

The number of pictures in each travel guide: ADAC 142; Lonely Planet 64; Groene Gids 197 and Capitool a little over 1000 (but the pictures from the sections accommodation \& restaurants, and practical information-160—-were not included)

Table 4 Alterity and othering in the pictures

\begin{tabular}{llccrr}
\hline & & ADAC & Lonely Planet & Groene Gids & Capitool \\
\hline Other times & Urban landscapes & $32 \%$ & $38 \%$ & $22 \%$ & $31 \%$ \\
\multirow{3}{*}{ Other experiences } & Rural landscapes & $11 \%$ & $8 \%$ & $15 \%$ & $17 \%$ \\
& Urban landscapes & $13 \%$ & $13 \%$ & $7 \%$ & $8 \%$ \\
& Rural landscapes & $8 \%$ & $3 \%$ & $4 \%$ & $15 \%$ \\
\hline
\end{tabular}

The use of othering in pictures of both urban and rural landscapes. A distinction is made between other times (heritage or nostalgia) and other experiences (leisure, nature, agriculture). The table presents percentages

The number of pictures in each travel guide: ADAC 142; Lonely Planet 64; Groene Gids 197 and Capitool a little over 1000 (but the pictures from the sections accommodation \& restaurants, and practical information-160-were not included)

(both in terms of type of tourist and national preferences). Michelin's Guide Vert pays a lot of attention to history and art history (monumental buildings, museums, collections). Lonely Planet informs its readers extensively about accommodation and places to eat. The pictures in the travel guide show a strong focus on urban areas. The ADAC travel guide emphasises a so-called collective gaze (Urry 1990). Half of the pictures contain people and most of them are engaged in leisure activities. Readers of this travel guide will expect to see other tourists. As German tourists traditionally visit the Dutch seaside, $A D A C$ pays more attention than the other guides to these areas.

The intentional and unintentional projected images of the Netherlands differ as well. Travel guides have more room for information in general and therefore more room for details. These guides do not rely strongly on stereotypes. Travel guides also look beyond Holland. They contain information about every province (see Figs. 1, 2). This implies that travel guides need to create an image for the other parts of the Netherlands as well. They do not rely on the Holland image for these areas. In contrast to the findings of Jansen (1994), the travel guides do not use the Holland landscapes for other regions nor is water visible in every picture of any landscape. The travel guides do use alterity again to create a regional geography of the Netherlands. Regions are projected as different to Holland and different from each other. Limburg and Brabant are presented as Catholic, the place for carnivals and imbued with bourgundian characteristics. Northern and eastern provinces have nature and/or agriculture. What is striking is that all three travel guides which divide the country into regions, use a different division (see Table 1).

The intentional and unintentional projected images differ also because travel guides have their own gaze, and this is usually an (art) historic gaze. Finally, one characteristic of the Netherlands that might be considered and a unique selling point is its liberal policies towards drugs, sex and ethical issues such as abortion and euthanasia. These topics are carefully kept out of the intentional projected images, even though the Netherlands are (in)famous where theses issues are concerned. The official promoters know that these characteristics do attract certain tourists (notably young, backpackers, homosexuals), but fear that other tourists (older and often spending more) may stop coming to the Netherlands if these controversy-ridden aspects were promoted. The travel 


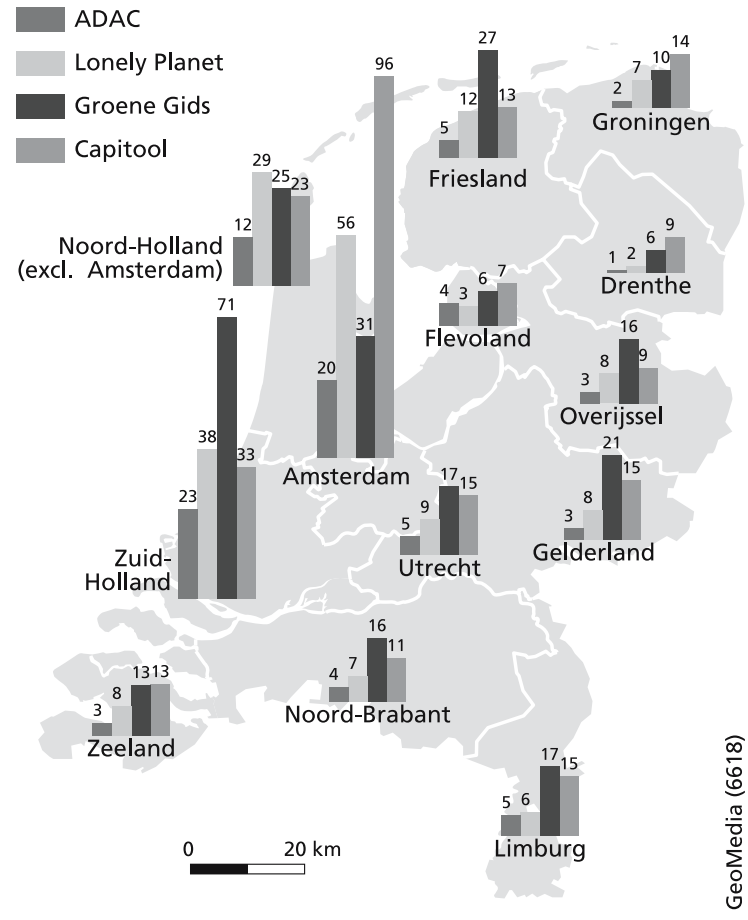

Fig. 2 Pages of place information on each province. The number of pages from the place information section of the travel guides describing (places in) the different provinces. Again Holland dominates the travel guides

guides inform tourists about the red light district of Amsterdam (de Wallen) and about for example the cannabis museum. The Lonely Planet also informs its reader about using soft drugs and even reviews a number of 'coffeeshops' in the same way it reviews restaurants and accommodation.

\section{Conclusion}

At first glance the intentional projected image (NBTC promotion at www.Holland.com) and the unintentional projected image (travel guides) seem to be constituted by the same stereotypes: tulips, windmills, cheese and clogs. However, further analysis shows that for travel guides these stereotypes are more for the purpose of window dressing: they are used for the front cover, but do not feature prominently in the write-ups and descriptions.

These travel guides can be seen to provide popular geographical knowledge. They each create a geography of the Netherlands. Travel guides tell tourists where to go and what to gaze upon. They use alterity both to position the Netherlands as a destination and to create a regional geography of the Netherlands. The overall image of the Netherlands is one of other times and other experiences. It is an image of a wellpreserved country, with fine historical buildings, streetscapes and landscapes where people are engaged in leisure activities such as sightseeing or having a drink in the sun. The whole country is reduced to a sort of open air museum or Nederdisney perhaps. Modern architecture (the most spectacular examples) is the hallmark of newer museums (e.g. the Groninger museum or the Bonnefanten museum). A contemporary image of the country with ordinary people is not to be found in the travel guides.

To create a regional geography alterity is mostly used to project what is not-Holland. Whereas the overall image denoting other times and other experiences is applied to the whole country, this does not apply to the Holland image. The southern provinces of Brabant and Limburg are presented as Catholic with a tradition of celebrating carnivals and the Wadden eilanden predominantly as a nature retreat. The chosen regional geographies do not seem to be based in geographical studies (for example Nederland in Delen by De Pater et al. (1989)). The ADAC, the Lonely Planet and the Capitool guide each use a different division. Michelin's Groene Gids discusses places in alphabetical order. This guide does not even attempt to create a regional geography or geographical image of the country.

It is clear that in these four travel guides geography is to a large degree absent. The gaze presented to the public is mainly an (art) historic gaze, which is directed at monumental buildings and museums.

\section{Discussion}

Focusing primarily on projected images implies that tourists are seen as passive receptors of the presented images. It is commonly suggested that tourist representations do influence or direct tourist behaviour, notably what tourists visit or gaze upon (Van der Vaart 1999). The concepts of the circle of representation and the tourist gaze likewise suggest that tourists have a pre-disposed 'gaze', which acts as self-fulfilling prophecy. However, little is known about how tourists interpret tourist information. 
Bockhorn (1997, p. 117) states that travel guides offer education, knowledge, values and norms, furthermore prejudices, clichés, sympathy, tolerance and understanding (and their opposites). This does not say anything about how tourists treat this information.

Some authors question the strength of projected images and the effectiveness of the tourist gaze. “Through the 1990's there has been much academic debate concerning Urry's 'tourist gaze' and many suggest that it is less relevant than Urry originally argued, particularly for some types of tourists", (Jenkins 2003, p. 310). Both McGregor (2000) and Jenkins (2003) studied the tourist gaze and the related circle of representation. They both chose their research subjects from groups of tourists that were believed to act more independently from projected images: travellers in Tana Toraja (Indonesia) and backpackers visiting Australia. Both studies, however, demonstrated the strength of projected images in shaping tourist behaviour.

Tourists to the Netherlands are thus likely to reproduce the projected images: they visit Amsterdam and some other historic towns, take pictures of tulips and windmills, visit a large museum such as Rijksmuseum or the Van Gogh museum and buy cheese and clogs. Still nothing is said about how tourists interpret the projected images. Tourists might be very well aware of the constructed, selective nature of projected images. A number of authors reported about a new kind of tourist, the so-called 'post-tourist' (Smith 2003; Williams 1998). Posttourists are said to express a certain playfulness in their tourism, because they are very well aware of the fact that they are tourists. "They are not deceived by the pseudo-realities of contemporary tourism but are happy to accept such constructions at face value as an expected and valued part of new forms of experience" (Williams 1998, p. 181). Even tough post-tourists are aware of the constructions, one might wonder whether they are experienced enough to develop a more in-depth perception of the country. The rise of the post-tourist therefore does not acquit geographers from creating popular geographical knowledge actually based on geography.

To know more about the image different groups of tourists have of the Netherlands, more research has to be carried out. Such research is necessary to find out how tourists interpret both the intentional and unintentional projected images of the Netherlands and their perceived image of the country before, during and after the visit.

Acknowledgements We would like to thank the anonymous reviewers for their helpful remarks.

\section{References}

Argreiter, M. (2000). Das Münchenbild in italienische Reiseführer. Geographische Rundschau, 52(3), 35-39.

Barends, S., Renes, J., stol, T., van Triest, J., De Vries, R., \& van Woudenberg, R. (1995). Het Nederlandse landschap. Een historisch geografische benadering (6th revised ed.). Utrecht: Matrijs.

Bhattacharyya, D. (1997). Mediating India. An Analysis of a Guidebook. Annals of Tourism Research, 24(2), 371-389.

Bell, D. (1995). Picturing the Landscape: Die Grüne Insel. European Journal of Communication, 10(1), 41-62.

Béneker, T. (2003). Images of The Netherlands: Representing the country. In B. Van Gorp, M. Hoff, \& H. Renes (Eds.), Dutch windows, cultural geographical essays on The Netherlands (pp. 81-90). Utrecht: Faculteit Ruimtelijke Wetenschappen.

Bockhorn, P. (1997). Wien is kein Stadt wie jede andere, zum aktuelle Wien-Bild in deutch sprächige Reiseführer. Frankfurt am Main: Peter Lang Europäischer Verlag der Wissenschaften.

Dahles, H. (1998). Redefining Amsterdam as a tourist destination. Annals of Tourism Research, 25(1), 55-69

Daniels, P., Bradshaw, M., Shaw, D., \& Sideway, J. (Eds.), (2005). An introduction to human geography. Issues for the 21 st century (2nd ed.). Harlow, UK: Pearson/Prentice Hall.

De Jong, A. (2001). De dirigenten van de herinnering, musealisering en nationalisering van de volkscultuur in Nederland 1815-1940. Nijmegen: SUN.

De Pater, B., Hoekveld, G., \& Van Ginkel, J. (Eds.), (1989). Nederland in delen: een regionale geografie. Houten: De Haan.

Dietvorst, A. (2002). De illusie gefotografeerd. Geografie, 11(6), 6-10.

Dietvorst, A., \& Ashworth G. (1995). Tourism transformations: an introduction. In: G. Ashworth \& A. Dietvorst (Eds.), Tourism and spatial transformations (pp. 1-12). Wallingford: CAB International.

Echtner, C., \& Prasad, P. (2003). The context of Third World Tourism Marketing. Annals of Tourism Research, 30(3), 660-682.

Gilbert, D. (1999). London in all its glory - or how to enjoy London: guidebook representations of imperial London. Journal of Historical Geography, 25(3), 279-297.

Goss, J. (1993). Placing the market and marketing place: tourist advertising of the Hawaiian Islands 1972-92. Environment and Planning D: Society and Space, II, 663-688.

Hopkins, J. (1998). Signs of the post-rural: Marketing myths of a symbolic Countryside. Geografiska Annaler, 80(2), 6581.

Jansen, M. (1994). Zicht op landschap, een verkennend onderzoek naar de betekenis van het Nederlandse landschap 
voor buitenlandse toeristen. Rapport werkgroep Recreatie en Toerisme 36, Wageningen.

Jenkins, O. (2003). Photography and travelbrochures: the circle of representation. Tourism Geographies, 5(3), 305-328.

Kneafsey, M. (1998). Tourism and place identity: A case-study in rural Ireland. Irish Geography, 31(2), 111-123.

Kotler, P., Haider, D., \& Rein I. (1993). Marketing places: Attracting investment, industry, and tourism to cities, states and nations. New York: Macmillan.

Kozma, G., \& Ashworth, G. (1993). Projected urban images: a comparison of Groningen and Debrehen. Groningen Studies 55.

Kunstbus, 2005: Haagse School [ONLINE] www.kunstbus.nl/ verklaringen/haagse_school.html, visited 03-06-2005.

Markwick, M. (2001) Postcards from Malta. Image, Consumption, Context. Annals of Tourism Research, 28(2), 417-438.

McGregor, A. (2000). Dynamic texts and tourist gaze, death, bones and buffalo. Annals of Tourism Research, 27(1), 27-50.

Munsters, W. (2001). Cultuurtoerisme, 3e druk. Leuven: Garant.

NBTC, 2005: Cityguide $>$ tourist offices $>$ day trip [ONLINE] www.Holland.com/Amsterdam/gb/ visited 18-05-2005

Nelson, V. (2005). Representation and images of people, place and nature in Genada's tourism. Geografiska Annaler, 87B(2), 131-143.

Smith, M. (2003). Issues in cultural tourism studies. London: Routledge.

Stott, A. (1998). Holland Mania. The unknown Dutch period in American art and culture. New York: Overlook Press.

Urry, J. (1990). The tourist gaze, leisure and travel in contemporary societies. London: Sage publications.

Urry, J. (1995). Consuming Places. London: Routledge.

Van Dam, F., Heins, S., \& Elbersen, B. (2002). Lay discourses of the rural and stated and revealed preferences for rural living. Some evidence of the existence of a rural idyll in the Netherlands. Journal of Rural Studies, 4, 461-476

Van der Vaart, R. (1998). Toeristische beelden van Parijs, de veranderende blik van reisgidsen. In J. Hauer, B. de Pater, L. Paul, \& K. Terlouw (Eds.), Steden en streken, geografische opstellen voor Gerard Hoekveld (pp. 193-210). Assen: Van Gorcum.

Van der Vaart, R. (1999). Athenebeelden in reisgidsen. Geografie Educatief 8(4), 29-33.

Van Gorp, B. (2003). Bezienswaardig? Historisch-geografisch erfgoed in toeristische beeldvorming. Van Gorcum: Eburon.

Van Gorp, B., \& Renes, H. (2003). Landscapes of pillarisation. In B. van Gorp, M. Hoff, \& H. Renes (Eds.), Dutch windows, cultural geographical essays on The Netherlands (pp. 76-79). Utrecht: Faculteit Ruimtelijke Wetenschappen.

Waitt, G. (1997) Selling paradise and adventure: Representations of landscape in the tourist advertising of Australia. Australian Geographical Studies, 35(1), 47-60.

Werthner, H., \& Klein, S. (1999). ICT and the changing landscape of global tourism distribution. Electronic Markets, 9(4)256-262.

Williams, S. (1998). Tourism geography. London: Routledge.

Travel guides

Gray, J. \& Acciano, R, (2004). Lonely Planet: The Netherlands (2nd ed.). Lonely Planet Publications Pty Ltd.

Harmans, G., (2002). Capitool reisgidsen: Nederland, 4e herziene druk. Van Reemst uitgeverij/Unieboek bv, ANWB bv and Dorling Kindersley Ltd.

Jürgens, A., (2004). ADAC Reiseführer: Niederlande, 3e neu bearbeitete Auflage. ADACVerlag GmbH, München.

De Groene Gids: Nederland, 2001. Michelin reisuitgaven. 